\title{
The Effects of Feeding Clinoptilolite on Hematology, Performance, and Health of Newborn Lambs
}

\author{
M. A. Norouzian • R. Valizadeh • A. A. Khadem • \\ A. Afzalzadeh - A. Nabipour
}

Received: 23 August 2009 / Accepted: 17 November 2009 /

Published online: 16 December 2009

(C) Springer Science+Business Media, LLC 2009

\begin{abstract}
The effects of feeding clinoptilolite on hematology, performance, and health of newborn Balouchi lambs were evaluated in this experiment. In a completely randomized design, 30 newborn lambs were allocated to three groups and fed by basal diet ( $\mathrm{C} 0$; without clinoptilolite) and $\mathrm{C} 1$ and $\mathrm{C} 2$ (the basal diet plus $1.5 \%$ and $3 \%$ clinoptilolite, respectively, for 6 weeks ( 3 weeks before and 3 weeks after weaning)). Blood samples were taken from all lambs, at the time when the animals were allocated to the experimental diet and at the end of each week of experiment, and analyzed for hematology, plasma fibrinogen, and total protein. Performance and health of all lambs were measured. Fecal consistency score and diarrhea severity were evaluated. There was no difference between lambs in case of hematological parameters. Lambs fecal consistency score and severity of diarrhea were lowest $(P<0.05)$ for lambs on $\mathrm{C} 1$ and $\mathrm{C} 2$ and highest for lambs on $\mathrm{C} 0$. Dry matter intake and feed conservation ratio were similar between the groups of lambs fed by different diets, but daily gain of lambs differed significantly $(P<0.05)$ and was higher in $\mathrm{C} 2$. It was concluded that addition of $3 \%$ clinoptilolite to starter diet of newborn lamb can reduce incidence and severity of diarrhea, although its effect on hematology and performance was negligible.
\end{abstract}

Keywords Newborn lamb $\cdot$ Clinoptilolite $\cdot$ Diarrhea $\cdot$ Performance

M. A. Norouzian $(\bowtie) \cdot A$. A. Khadem $\cdot$ A. Afzalzadeh

Department of Animal Science, Abourayhan Pardis, University of Tehran, P.O. Box 11365-4117, Tehran, Iran

e-mail: manorouzian@ymail.com

R. Valizadeh

Department of Animal Sciences, College of Agriculture, Ferdowsi University of Mashhad, Mashhad, Iran

A. Nabipour

Department of Anatomical Sciences, College of Veterinary Medicine, Ferdowsi University of Mashhad, Mashhad, Iran 


\section{Introduction}

Use of silicate minerals in animal nutrition has recently increased, mainly due to their some position effects on animal performance and health. Katsoulos et al. [1] reported that cow fed with ration containing $2.5 \%$ clinoptilolite had significantly fewer cases of clinical ketosis during the first week after calving and a higher milk yield. The benefit of clinoptilolite addition to ration on health and performance of weaned, growing, and finishing pigs was studied by Papaioannou et al. [2].

The effects of zeolite supplementation on hematology and serum biochemistry of dairy cows, sheep, and sows have been studied by many workers [1, 3-8]. In addition, there are few existing studies concerning the effects of clinoptilolite supplementation on performance, wool growth, decreased ruminal ammonia concentration, and improved feed and bacterial protein flow to the small intestine [9-11].

Few existing studies concerning the effects of zeolite supplementation on performance, health, hematology, proteins, and immunoglobulin concentration in serum of newborn milkfed dairy calves and lambs [12-16] but limited reported data on the use of clinoptilolite in newborn lamb that started dry feed consumption are available.

Many management schemes and dietary adjustments in newborn ruminant have been attempted in an effort to promote dry feed intake, reducing stress, and health problems especially diarrhea. The objectives of the present study were to determine the effects of clinoptilolite supplementation in starter feed of pre- and post-weaning Balouchi lambs on hematology, serum proteins, performance, and health of newborn lambs.

\section{Materials and Methods}

\section{Lambs and Management}

Thirty Balouchi lambs were allocated to the experimental diets. The lambs were separated from their dams 3 weeks after lambing. Lambs were allowed to be with the ewes for $30 \mathrm{~min}$ twice daily. Lambs were weaning at 6 weeks of age. Average live weight of lambs was $6.5 \pm$ $1.2 \mathrm{~kg}$ at the stage of their allocation to the treatments ( 3 weeks of age). Lambs were housed in straw-bedded pens. Pen's lambs were equipped with individual feedboxes and plastic troughs for providing the constant supply of fresh water.

\section{Feed and Treatments}

Lambs were given free access to the experimental diets which were a basal diet (C0) and clinoptilolite diets ( $\mathrm{C} 1$ or $\mathrm{C} 2$ ). $\mathrm{C} 1$ and $\mathrm{C} 2$ were formulated by supplementation of $\mathrm{C} 0$ diet with clinoptilolite at levels of $1.5 \%$ and $3 \%$, respectively (Table 1 ). Chemical composition of the clinoptilolite used in this study was: $66.59 \% \mathrm{SiO}_{2}, 11.21 \% \mathrm{Al}_{2} \mathrm{O}_{3}, 2.50 \% \mathrm{Na}_{2} \mathrm{O}$, $2.49 \% \mathrm{MgO}, 1.84 \% \mathrm{Fe}_{2} \mathrm{O}_{3}, 0.12 \% \mathrm{~K}_{2} \mathrm{O}, 0.19 \% \mathrm{CaO}, 0.02 \% \mathrm{TiO}_{2}, 0.02 \mathrm{P}_{2} \mathrm{O}_{5}, 0.00 \% \mathrm{MnO}$, and loss on ignition $14.28 \%$ (Farzan Powder Co., Iran).

Diets were formulated according to NRC 1985 recommendations in order to provide potential growth (Table 1). Feed intake was daily recorded in morning.

During 3-6 weeks of age, milk consumption was recorded by weighing before and after suckling. Every week, two samples of ewes' milk were taken for subsequent analysis. The lambs were also given free and continuous access to fresh water. 
Table 1 Ingredients and Chemical Composition of the Experimental Diets (DM\%)

\begin{tabular}{lccc}
\hline & Group $^{\mathrm{a}}$ & & $\mathrm{C} 2$ \\
\cline { 2 - 4 } & $\mathrm{C} 0$ & $\mathrm{C} 1$ & 61.5 \\
\hline Ingredient & & & 23.65 \\
Corn & 59.5 & 60.5 & 4.6 \\
Soybean meal & 21.25 & 22.25 & 5 \\
Wheat bran & 12 & 8.5 & 3 \\
Molasses beet & 5 & 5 & 1.5 \\
Clinoptilolite & 0 & 1.5 & 0.25 \\
Limestone meal & 1.5 & 1.5 & 0.5 \\
White salt & 0.25 & 0.25 & 3.1 \\
Vitamin-mineral premix ${ }^{\mathrm{b}}$ & 0.5 & 0.5 & 18 \\
Chemical composition & & & 11.8 \\
ME (Mcal/kg) & 3.1 & 3.1 & 3.9 \\
CP\% & 18 & 18 & 2.96 \\
NDF\% & 13.4 & 12.9 & 64.62 \\
ADF\% & 4.5 & 4.2 & 0.7 \\
Ash\% & 3.11 & 3.03 & 0.35 \\
NFC \% & 62.25 & 63.32 & 0.69 \\
Ca \% & 0.68 & 0.37 & \\
P\% & 0.39 & & \\
\hline
\end{tabular}

NFC nonfiber carbohydrates calculated as $100-(\mathrm{CP}+\mathrm{Ash}+\mathrm{NDF}+\mathrm{EE})$

${ }^{\text {a }} \mathrm{C} 0$ : basal diet (no clinoptilolite), $\mathrm{C} 1$ and $\mathrm{C} 2$ diets supplemented by clinoptilolite at levels of $1.5 \%$ and $3 \%$, respectively

${ }^{\mathrm{b}}$ Each kilogram of vitamin-mineral premix contained: Vitamin A (50,000 IU), Vitamin D3 (10,000 IU), Vitamin E (0.1 g), Calcium (196 g), Phosphorus (96 g), Sodium (71 g), Magnesium (19 g), Iron (3 g), Copper (0.3 g), Manganese (2 g), Zinc (3 g), Cobalt (0.1 g), Iodine (0.1 g), Selenium (0.001 g)

\section{Blood Sampling and Performance}

Blood samples were taken from the jugular vein at the beginning of the experiment (day 0) and the end of each week (up to week 6). Two milliliters of blood samples were anticoagulated with EDTA for hematological analysis, and plain tubes supplied serum for analysis of total protein. The serum was separated after centrifugation at $1,800 \times \mathrm{g}$ for $10 \mathrm{~min}$ and stored at $-18^{\circ} \mathrm{C}$ until analysis.

Anticoagulated blood samples were analyzed shortly after collection for: packed cell volume (PCV), number of red blood cells (RBC), hemoglobin concentration ( $\mathrm{Hb})$, total leukocyte count (WBC), mean corpuscular hemoglobin $(\mathrm{MCH})$, mean corpuscular hemoglobin concentration, and mean corpuscular volume (MCV) by an automatic veterinary hematology cell counter (Nihon kohden, Celltac $a$, Tokyo, Japan). Differential leukocyte counts were performed on routinely prepared Giemsa stained blood films using the cross-sectional technique. Fibrinogen concentration was estimated by heat precipitation method [17]. Stored serum samples were analyzed for total protein, Biuret method [18] by commercial kits (Pars Azmoon, Tehran, Iran) using the spectrophotometer (Jenway 6105, Jenway, Felstead, England). 
Lambs were weighed weekly until the end of experiment. Dry matter intake (DMI), body weight gain, and feed conversion ratio (FCR) were calculated.

Fecal consistency score and severity of diarrhea were assessed visually and characterized as: $1=$ firm pellets, $2=$ normal pellets, $3=$ soft pellets, $4=$ soft (no pellets) but not running, $5=$ soft and running according to Lema et al. [19]. Scores of 4 and 5 were considered to be diarrhea.

\section{Statistical Analysis}

The data were analyzed by SAS 9.1 version statistical package. Because blood parameters were measured over the time; a repeated measures approach using ANOVA with mixed linear models in SAS was used. Interactions between treatments and time (weeks 1 to 6) were tested. Initial body weight was evaluated in the model as a covariate. When differences were significant $(P<0.05)$, means were separated using Duncan's test [20].

\section{Result}

The results are summarized in Tables 2, 3, and 4 and Figs. 1 and 2. Group had no significant effect on hematological parameters. Sampling time had no significant effects on the most measured parameters except MCV and fibrinogen (Figs. 1 and 2). High amount of MCV was observed in week 1 and decreases with time sampling but no trend for fibrinogen detected.

The lamb fecal score and severity of diarrhea and mortality are presented in Table 3. Lamb fecal consistency scores and severity of diarrhea were lowest $(P<0.05)$ for lambs on

Table 2 Effects of Clinoptilolite Supplementation on Hematological Parameters

\begin{tabular}{|c|c|c|c|c|c|c|c|}
\hline \multirow[t]{2}{*}{ Parameters } & \multicolumn{3}{|l|}{ Group $^{a}$} & \multirow[t]{2}{*}{ SEM } & \multicolumn{3}{|l|}{ Effects } \\
\hline & $\mathrm{C} 0$ & $\mathrm{C} 1$ & $\mathrm{C} 2$ & & Group & Week & Group $\times$ week \\
\hline PCV (\%) & 31.70 & 31.88 & 36.10 & 1.54 & NS & NS & NS \\
\hline $\operatorname{RBC}\left(10^{12} / \mathrm{L}\right)$ & 10.83 & 10.95 & 11.60 & 0.35 & NS & NS & NS \\
\hline $\mathrm{Hb}(\mathrm{g} / \mathrm{L})$ & 105.45 & 106.35 & 114.78 & 4.47 & NS & NS & NS \\
\hline MCV (fL) & 28.33 & 27.63 & 32.56 & 2.73 & NS & S & NS \\
\hline $\mathrm{MCH}$ (pg) & 9.61 & 9.70 & 10.36 & 0.74 & NS & NS & NS \\
\hline MCHC (\%) & 34.01 & 34.08 & 32.30 & 0.51 & NS & NS & NS \\
\hline WBC $\left(10^{9} / \mathrm{L}\right)$ & 7.62 & 9.51 & 10.36 & 0.86 & NS & NS & NS \\
\hline Neut $\left(10^{9} / \mathrm{L}\right)$ & 3.72 & 4.21 & 4.00 & 0.74 & NS & NS & NS \\
\hline Lymph $\left(10^{9} / \mathrm{L}\right)$ & 3.06 & 3.62 & 4.03 & 0.57 & NS & NS & NS \\
\hline Mono $\left(10^{9} / \mathrm{L}\right)$ & 0.60 & 1.56 & 2.17 & 0.13 & NS & NS & NS \\
\hline Fib (g/L) & 3.25 & 2.55 & 3.95 & 0.37 & NS & $\mathrm{S}$ & NS \\
\hline $\mathrm{TP}(\mathrm{g} / \mathrm{L})$ & 59.16 & 56.27 & 63.16 & 2.96 & NS & NS & NS \\
\hline
\end{tabular}

${ }^{a} \mathrm{C} 0$ : basal diet, $\mathrm{C} 1$ and $\mathrm{C} 2$ diets supplemented by clinoptilolite at levels of $1.5 \%$ and $3 \%$, respectively $S$ significant effect $(P<0.05), N S$ not significant effect, $P C V$ packed cell volume; $R B C$ red cell count; $H b$ hemoglobin; $M C V$ mean corpuscular volume; $M C H$ mean corpuscular hemoglobin; $M C H C$ mean corpuscular hemoglobin concentration; WBC white blood cell count; Neut neutrophil; Lymph lymphocyte; Mono monocyte; Fib fibrinogen; TP total protein 
Table 3 Lambs Fecal Score, Diarrhea Severity, and Mortality

\begin{tabular}{lllll}
\hline Parameters & \multicolumn{2}{l}{ Group $^{\mathrm{a}}$} & & SEM \\
\cline { 2 - 5 } & $\mathrm{C} 0$ & $\mathrm{C} 1$ & $\mathrm{C} 2$ & \\
\hline Fecal score & $3.00 \mathrm{a}$ & $2.33 \mathrm{~b}$ & $1.40 \mathrm{c}$ & 0.21 \\
Lamb days with diarrhea (\%) & $32 \mathrm{a}$ & $16 \mathrm{~b}$ & $14 \mathrm{~b}$ & 2.21 \\
Mortality status & 1 & 0 & 0 & - \\
\hline
\end{tabular}

Means with different letters within a row differ significantly $(P<0.05)$

${ }^{\mathrm{a}} \mathrm{C} 0$ : basal diet, $\mathrm{C} 1$ and $\mathrm{C} 2$ diets supplemented by clinoptilolite at levels of $1.5 \%$ and $3 \%$, respectively

$\mathrm{C} 2$ and $\mathrm{C} 1$ and highest for lambs on $\mathrm{C} 0$ diet. Overall, one lamb of the group on $\mathrm{C} 0$ diet died in week 4 of the experiment.

Although no difference was found between lambs in DMI and FCR, their daily gains differed significantly $(P<0.05)$ and the average means for the groups of lambs on diets $\mathrm{C} 0$, $\mathrm{C} 1$, and $\mathrm{C} 2$ were $136.32,138.58$, and $170.56 \mathrm{~g} /$ day, respectively (Table 4).

\section{Discussion}

As it was noted, no difference was observed between the lambs for the hematology parameters. No data in this contest were found in the available literature for lambs. However, Hutcheson [21] reported no difference for PCV in calves fed by diet supplemented with 3\% clinoptilolite during 56 days of age. In another study, Katsoulos et al. [7] reported no effect of long-term clinoptilolite supplementation at $1.25 \%$ and $2.5 \%$ levels for dairy cows on RBC and PCV measures. Bartko et al. [4] suggested that addition of clinoptilolite at a rate of $0.15 \mathrm{~g} / \mathrm{kg}$ of live weight per day for 3 months in sheep had no effect on RBC number. Martin-Kleiner et al. [22] suggested that the addition of clinoptilolite for 6 weeks did not cause significant alterations on PCV values in mice.

In contrast, few studies which show supplementation of milk by clinoptilolite reveal significant effect on hematology parameters especially $\mathrm{Hb}$ concentration. In short-term supplementation of clinoptilolite in colostrum and milk, Mohri et al. [15] showed that $\mathrm{Hb}$ concentration increased by supplementation at a rate of $2 \%$ of each colostrums meal for 14 days. Similar results were also obtained by supplementation of colostrums and milk of

Table 4 Mean \pm SE of Total Performance Between Trial Groups

\begin{tabular}{|c|c|c|c|c|}
\hline \multirow[t]{2}{*}{ Parameters } & \multicolumn{3}{|l|}{ Group $^{a}$} & \multirow[t]{2}{*}{ SEM } \\
\hline & $\mathrm{C} 0$ & $\mathrm{C} 1$ & $\mathrm{C} 2$ & \\
\hline DMI (g/day) & 364.71 & 357.73 & 422.01 & 18.25 \\
\hline Gain (g/day) & $136.32 b$ & $138.58 b$ & $170.56 \mathrm{a}$ & 4.52 \\
\hline FCR & 2.62 & 2.50 & 2.48 & 0.07 \\
\hline
\end{tabular}

Means with different letters within a row differ significantly $(P<0.05)$

${ }^{\mathrm{a}} \mathrm{C} 0$ : basal diet and $\mathrm{C} 1$ and $\mathrm{C} 2$ diets supplemented by clinoptilolite at levels of $1.5 \%$ and $3 \%$, respectively 


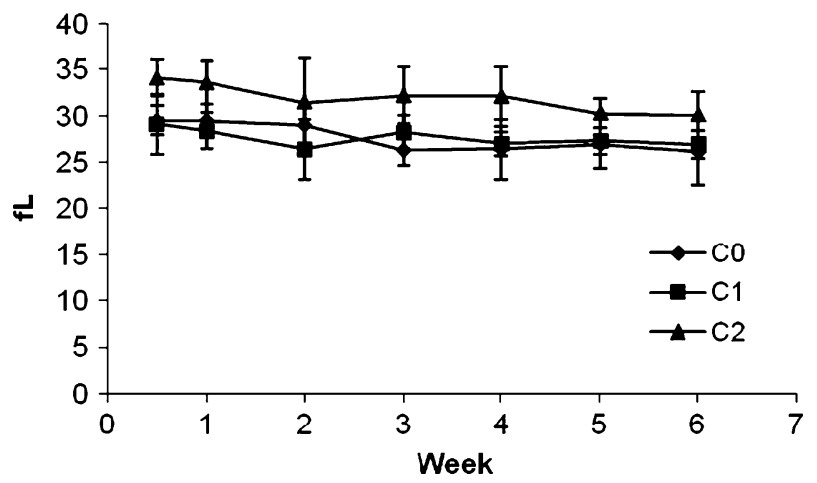

Fig. 1 MCV (SEM) in clinoptilolite-treated and control groups

the newborn calves with clinoptilolite at a rate of $1 \mathrm{~g} / \mathrm{kg}$ live weight for the first 15 days of life [23].

In newborn animals, increasing of RBC concentration was reported by researchers [15, 21]. Mohri et al. [15] believed that this increasing could be attributed to a possible increase of iron concentration due to clinoptilolite supplementation for 14 days to the calves. Based on the results of Verzgula et al. [23] and Mohri et al. [24], supplementation of clinoptilolite in colostrums and milk can promote iron absorption and/or utilization in dairy calves. The different alimentary system physiology with adult ruminant and/or duration of supplementation could be responsible for the different response after clinoptilolite supplementation. The iron reserves of the calf, primarily in the liver, are generally sufficient to prevent serious anemia if calves or lambs are fed dry feeds beginning at a few weeks of age. If calves are fed a milk diet exclusively for several weeks, then they may develop iron deficiency anemia, which can adversely affect growth and feed conversion [25]. In animals that consume dry feed, requirement of iron could be supplied by the diet, but in milk-fed lambs and calves, iron requirements could not be supplied due to low iron in milk. Hutcheson [21] suggested that zeolite supplies a significant amount of iron in available form for cattle in the diet.

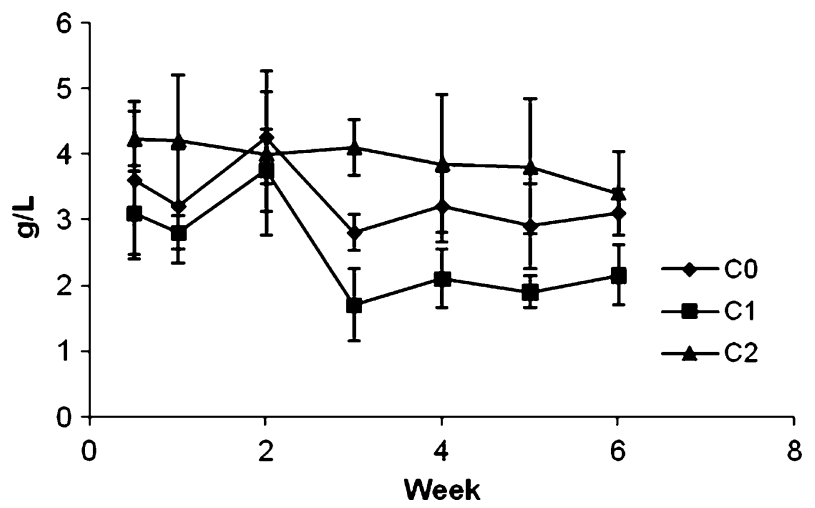

Fig. 2 Fibrinogen content (SEM) in Clinoptilolite treated and control groups 
No significant effect of clinoptilolite supplementation on WBC count in sheep [4] and dairy cow [7] has been reported. In contrast, Petkova et al. [26] suggested significant changes with increased numbers of granulocytes and lymphocytes in newborn calves following 15 days supplementation of clinoptilolite in milk. Increased leukocyte count, mainly lymphocytes, was reported in mice supplemented with clinoptilolite [22].

In accordance to our result, no significant changes in serum total protein by short-term [15] and long-term [1] supplementation of clinoptilolite in colostrum and milk in newborn calves and growing lambs have been reported [27].

The results of this study confirmed the effectiveness of clinoptilolite on reduction of incidence, severity, and duration of diarrhea in newborn animals as reported by other workers $[12,28-30]$. Feeding zeolite led to the better general health of the calves, mainly their resistance to diseases [15]. Bartko et al. [31] revealed the effectiveness of $68.7 \%$ compared to $18 \%$ in preventing of diarrhea following on supplementation by natural zeolite at a dose rate of $1 \mathrm{~g} / \mathrm{kg}$ of body weight versus control calves, respectively. Mumpton and Fishman [28] believed that silicate mineral retarding effect on intestinal passage rate and their water adsorption property leads to the appearance of drier and more compact feces. Zeolite may support the growth of nitrogen-loving bacteria that contribute to the health of the animals; the zeolite may take up deleterious heavy metals, or it may simply regulate $\mathrm{pH}$ in the gut system, resulting in fewer or less severe stomach ailments [32].

The ameliorative effect of clinoptilolite on diarrhea of calves may result from either the alteration of metabolic acidosis, through effects on osmotic pressure in the intestinal lumen, or the increased retention of the enterotoxigenic Escherichia coli. Clinoptilolite is capable to adsorb and partially inactivate enterotoxin of E. coli, thus constricting its attachment to the intestinal cell membrane receptors [33].

Lambs on $\mathrm{C} 2$ had highest DMI but did not differ with lambs on $\mathrm{C} 0$ and $\mathrm{C} 1$ which ended to a higher daily gain $(P<0.05)$ and a slightly better FCR.

Petkova et al. [34] reported around 19\% more daily gain in growing lambs fed by diets supplemented with 4\% zeolite. Pajovic et al. [35] also noted better average daily gain and total gain in fed-milk calves following zeolite supplementation for 75 days.

The higher daily gain and the improved FCR might be explained by increased feed and microbial protein supply to the small intestine of lambs fed clinoptilolite supplemented diets compared to that in lambs of control group. Mumpton [36] compared dietary use of natural zeolite with control diets for poultry, swine, and ruminants and suggested that efficient use of nutrients in animal production could be due to the integral mechanism of ion exchange and adsorption properties of the zeolite used. Zeolites, due to the presence of alumina, exhibit a negatively charged framework counterbalanced by positive cations, resulting in a strong electrostatic field on the internal surface. These cations can be exchanged to fine-tune the pore size or the adsorption characteristics. Mohri et al. [15] suggested that better weight gain may be caused by the zeolite acting as ammonium reservoir in the gastrointestinal tract, thereby allowing the animal to use ingested nitrogen more efficiently, but it seems this effect created after long-term supplementation.

It was concluded that diet supplementation with clinoptilolite may not affect hematological parameters significantly, but their utilization in the appropriate levels could lead to better health and daily gain in newborn lambs.

Acknowledgements The authors would like to thank Prof. M. Mohri for his comments and Farzan Powder Co. for material support. 


\section{References}

1. Katsoulos PD, Panousis N, Roubies N, Christaki E, Arsenos G, Karatzias H (2006) Effects of long-term feeding of a diet supplemented with clinoptilolite to dairy cows on the incidence of ketosis, milk yield, and liver function. Vet Rec 159:415-418

2. Papaioannou DS, Kyriakis CS, Alexopoulos C, Tzika ED, Polizopoulou ZS, Kyriakis SC (2004) A field study on the effect of the dietary use of a clinoptilolite-rich tuff, alone or in combination with certain antimicrobials, on the health status and performance of weaned, growing and finishing pigs. Res Vet Sci $76: 19-29$

3. Verzgula L, Bartko P, Blazovsky J, Kozac J (1982) The effect of feeding clinoptilolite on the health status, blood picture and weight gain in pigs. Vet Med (Praha) 27:267-274

4. Bartko P, Verzgula L, Prosbova M, Blazovsky J (1983) The effect of feeding zeolite (clinoptilolite) on health status of sheep. Vet Med (Praha) 28:481-492

5. Katsoulos PD, Panousis N, Roubies N, Christaki E, Karatzias H (2005) Effects on blood concentrations of certain serum fat-soluble vitamins of long-term feeding of dairy cows on a diet supplemented with clinoptilolite. J Vet Med 52:157-161

6. Katsoulos PD, Roubies N, Panousis N, Arsenos G, Christaki E, Karatzias H (2005) Effects of long-term dietary supplementation with clinoptilolite on incidence of parturient paresis and serum concentrations of total calcium, phosphate, magnesium, potassium, and sodium in dairy cows. Am J Vet Res 66:2081-2085

7. Katsoulos PD, Roubies N, Panousis N, Christaki E, Karatzanos P, Karatzias H (2005) Effects of long term feeding dairy cows on a diet supplemented with clinoptilolite on certain haematological parameters. Vet Med Czech 50:427-431

8. Katsoulos PD, Roubies N, Panousis N, Karatzias H (2005) Effects of long-term feeding dairy cows on a diet supplemented with clinoptilolite on certain serum trace elements. Biol Trace Elem Res 108:137-145

9. Walz LS, White TW, Fernandez JM, Gentry LR, Blouin DC, Froetschel MA, Brown TF, Lupton CJ, Chapa AM (1998) Effects of fish meal and sodium clinoptilolite on daily gain, wool growth, carcass characteristics, and ruminal and blood characteristics of lambs fed concentrate diets. J Anim Sci 76:2025-2031

10. Fenn PD, Leng RA (1989) Wool growth and sulfuraminoacid entry rate in sheep fed roughage based diet supplemented with clinoptilolite and sulfuraminoacids. Aust J Agric Res 40:889-896

11. Fenn PD, Leng RA (1990) The effect of clinoptilolite supplementation on ruminal protozoa density and wool growth in sheep either fed roughage based diets or grazing. Aust J Agric Res 41:167-174

12. Stojic V, Samanc H, Fratric N (1995) The effect of a clinoptilolite based mineral adsorber on colostral immunoglobulin $\mathrm{G}$ absorption in newborn calves. Acta Vet (Beograd) 45:67-74

13. Fratric N, Stojic V, Jankovic D, Samanc H, Gvozdic D (2005) The effect of a clinoptilolite based mineral adsorber on concentrations of immunoglobulin $\mathrm{G}$ in the serum of newborn calves fed different values of colostrums. Acta Vet (Beograd) 55:11-21

14. Gowda NK, Suganthi SRU, Malathi V, Raghavendra A (2007) Utilization of dietary minerals and blood biochemical values in lambs fed hydrated sodium calcium alumino silicate sorbent material at supplementary level. Small Rumin Res 69:17-22

15. Mohri M, Seifi HA, Daraei F (2008) Effects of short-term supplementation of clinoptilolite in colostrum and milk on hematology, serum proteins, performance, and health in neonatal dairy calves. Food Chem Toxicol 46:2112-2117

16. Sadeghi AA, Shawrang P (2008) Effects of natural zeolite clinoptilolite on passive immunity and diarrhea in newborn Holstein calves. Livestock Science 113:307-310

17. Jain NC (1986) Schalms veterinary hematology. Lea and Febiger, Philadelphia, pp 12-58

18. Tomas H (1998) Clinical laboratory diagnostics, 1st edn. TH Books, Frankfurt, pp 208-647

19. Lema M, Williams L, Rao DR (2001) Reduction of fecal shedding of enterohemorrhagic Escherichia coli $\mathrm{O} 157: \mathrm{H7}$ in lambs by feeding microbial feed supplement. Small Rumin Res 39:31-39

20. Steel R, Torrie JH (1980) Principles and procedures of statistics: a biometrical approach, 2nd edn. McGraw Hill, New York

21. Hutcheson DP (1984) Addition of clinoptilolite ores to the diets of feeder cattle, zeo-agriculture. In: Pond WG, Mumpton FA (eds) Use of natural zeolites in agriculture and aquaculture. Westview, Boulder, pp 195-199

22. Martin-Kleiner I, Flegar-Mestric Z, Zadro R, Breljak D, Stanovic Janda S, Stojkovic S, Marusic M, Radacic M, Boranic M (2001) The effect of zeolite clinoptilolite on serum chemistry and hematopoesis in mice. Food Chem Toxicol 39:717-727

23. Verzgula L (1986) The effect of natural zeolite (clinoptilolite) on the state of health and the indices of the internal environment of calves during the first 15 days of postnatal development. Nutr Rep Int 34:11051113 
24. Mohri M, Seifi HA, Maleki M (2008) Effects of short-term supplementation of clinoptilolite in colostrums and milk on the concentration of some serum minerals in neonatal dairy calves. Biol Trace Elem Res 123:116-123

25. National Research Council (NRC) (2001) Nutrient requirements of dairy cattle, 7th edn. National Academic Press, Washington, DC

26. Petkova E, Venkov T, Chushkov P, Dzhurov A, Stefanov T, Poschakov E, Chelebieva S (1982) Bulgarian potassium calcium zeolite as apreventive for digestive disorders in calves. Vet Med Nauki 19:55-62

27. Pond WG, Laurent SM, Orlo HD (1984) Effect of dietary clinoptilolite or zeolite Na-A on body weight gain and feed utilization of growing lambs fed urea on intact protein as a nitrogen supplement. Zeolites 4:127-132

28. Mumpton FA, Fishman PH (1977) The application of natural zeolites in animal science and aquaculture. J Anim Sci 45:1188-1194

29. Rodriguez-Fluentes G, Barrios MA, Iraizoz A, Perdomo I, Cedre B (1997) Enterex-anti-diarrheic drug based on purified natural clinoptilolite. Zeolites 19:441-448

30. Nikkhah A, Sadeghi AA, Shahrebabak MM (2002) Effects of clinoptilolite on homo-immuno parameters and health status of newborn calves. In: Misaelidis P (ed) Zeolite '02, occurrence, properties and utilization of natural zeolites, 6th Int. Conf., Thessaloniki, Greece, pp 253

31. Bartko P, Seidel H, Kovac G (1995) Use of clinoptilolite from slovakiain animal production: a review. In: Ming DW, Mumpton FA (eds) Natural zeolite. 93, 467-475

32. Mumpton FA (1999) La roca magica: uses of natural zeolites in agriculture and industry. Proc Natl Acad Sci USA 96:3463-3470

33. Ramu J, Clark K, Woode GN, Sarr AB, Phillips TD (1997) Adsorption of cholera and heat-labile Escherichia coli enterotoxins by various adsorbents: an invitro study. J Food Prot 60:358-362

34. Petkova E, Venkov T, Stanchev K (1983) Effects of Bulgarian potassium calcium zeolites on the assimilation of macro and trace elements in lambs. Vet. Med. Nauki. 20:36-40

35. Pajovic M, Radovanovic T, Radovic V, Vukicevic O (1998) The application of zeolite preparation Minazel in feeding of suckling calves. In: Stojanovic S (ed) Feed processing technology from standpoint of ecology (Proceedings of a Symposium), pp 164-171

36. Mumpton FA (2006) Using zeolites in agriculture: zeolite product website. Available at http://www. zeolite-products.com (accessed April 2007) 